Case report

\title{
Toxic hepatitis caused by the excretions of the Phyllomedusa bicolor frog - a case report
}

\author{
Joanna Pogorzelska, Tadeusz W. Łapiński \\ Department of Infectious Diseases and Hepatology, Medical University of Bialystok, Poland
}

\begin{abstract}
The Kambô ritual consists of various types of skin scarification and subsequent application of Phyllomedusa bicolor secretion to the fresh wounds. In Europe, the ritual of Kambô is becoming more popular, but its use can lead to serious multiple organ damage, sometimes life-threatening. Our manuscript shows a patient with toxic liver damage probably associated with the Kambô ritual.
\end{abstract}

Key words: liver damage, Phyllomedusa bicolor, Kambô ritual.

\section{Address for correspondence}

Prof. Tadeusz W. Łapiński, Department of Infectious Diseases and Hepatology, Medical University of Bialystok, 14 Żurawia St., 15-540 Bialystok, Poland, e-mail: twlapinski@gmail.com

\section{Introduction}

The Kambô or Sapo ritual is performed in numerous countries in South America for purification of the body. This ritual consists of various types of skin scarification, and subsequently secretion of Phyllomedusa bicolor (giant leaf frog or kambô) is applied to the fresh wounds. In Europe, the ritual of Kambô is becoming more popular, but its use can lead to serious multiple organs damage, sometimes life-threatening [1]. Most often, the ritual causes: nausea, vomiting, muscle weakness, spasms, seizure, confusion, lethargy, and memory loss [2].

In many European countries body purification and natural medicine are becoming increasingly popular. The widespread use of the Kambô ritual can result in unexpected adverse events and entail serious organ injury and even death.

\section{Case report}

A 34-year-old man was admitted to hospital due to icterus, skin itching, weakness, and pain in the upper abdomen. Symptoms occurred a few days before hospitalisation. The patient had consumed three beers a day for the previous two years and sometimes smoked cannabis. The patient had stopped drinking alcohol and smoking cannabis for the previous two months. During that time, once a week, he performed the ritual of Kambô, using poison from Phyllomedusa bicolor to maintain abstinence of drinking, smoking, and to purify the body.

At physical examination a slight icterus and overweight $(\mathrm{BMI}=26)$ was found. We saw also a curious scar on the abdomen (Fig. 1), which consisted of five regularly spaced and aligned dots. Laboratory tests showed elevated liver enzymes: ALT - 2155 U/l, AST - $878 \mathrm{U} / \mathrm{l}$, GGTP - $203 \mathrm{U} / \mathrm{l}$, bilirubin concentration $3.02 \mathrm{mg} / \mathrm{dl}$, prothrombin time - 14.2 seconds, ammonia concentration - $137 \mathrm{mg} / \mathrm{dl}$, and creatinine concentration - $1.03 \mathrm{mg} / \mathrm{dl}$. Abdominal ultrasound presented increased echogenicity of the liver; other organs of the abdominal cavity were without pathological changes. We excluded HBV, HAV, HCV, CMV, EBV, and HIV infection, as well as haemosiderosis, AIH, and Wilson's disease. The patient received symptomatic treatment including lactuloses, silymarin, and ornithine.

After 10 days of treatment, the patient's test results improved. The patient was subsequently discharged home in good clinical condition.

\section{Discussion}

The secretion occurring on the skin of Phyllomedusa bicolor contains different, not precisely known toxins. Mucus has deltorphin and dermorphin, which are potent 


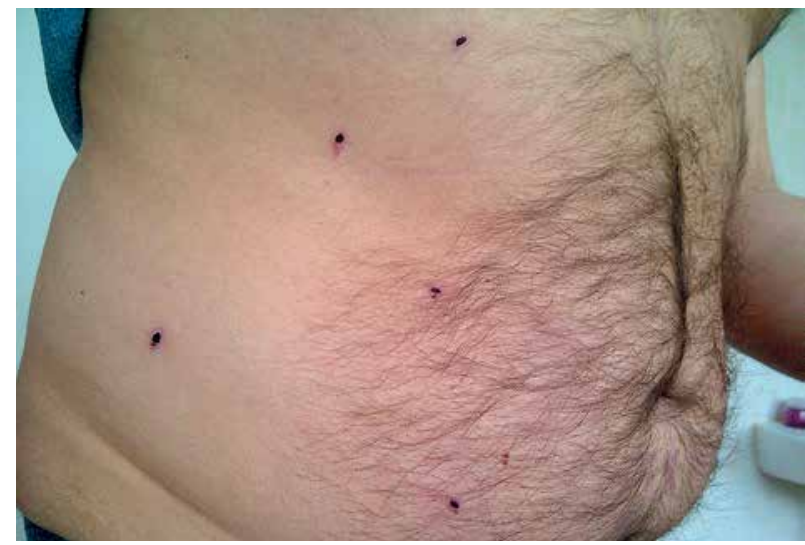

Fig. 1. Changes in the skin after Kambô procedure

opioid delta receptor agonists, 4000 times more potent than morphine and 40 times more potent than endogenous $\beta$-endorphin. These substances relieve pain as well as morphine but also affect the central nervous system (CNS), causing respiratory depression and heavy reliance [3]. A tachykinin in mucus phyllomedusin influences smooth muscle spasm. Moreover, it affects intestinal spasms and respiratory discharge secretions from the salivary glands and tear ducts. The peptide dermaseptin (DRS) B2 has also been isolated in the secretion, which exhibits strong anti-tumour activity, not by activation of apoptosis, but by stimulation of tumour cell necrosis [4]. The next compounds isolated from the secretions were phyllokinin PS-B and phylloseptin, which possess antimicrobial and antiviral activity (especially against herpes viruses). In addition, the toxins dilate blood vessels and increase the permeability of the blood-brain barrier. Phyllocaerulein detected in mucus stimulates the adrenal cortex and pituitary gland, causing a decrease in blood pressure, tachycardia, and increased secretion of bile and pancreatic enzymes. Sauvagine, like phyllocaerulein, stimulates the adrenal cortex affecting long-term drop in blood pressure and tachycardia. Adenoregulin is a toxin that affects the activation of adenosine receptors, resulting in an increase in the metabolism of high-energy compounds, as well as the regulation of cardiac function and antidepressant. The discharge frog Phyllomedusa bicolor is not completely understood, and its various toxins can have cytotoxic effects on various cells [5].

The most common cases of illness and death after Kambô rituals are associated with the depressive impact of derivatives of opioids on the CNS and the effects of toxins on the cardiovascular system. However, kidney, pancreas, and liver might be damaged by toxins [6].

In the described case, there is an association between liver damage and Kambô performed a ritual. Toxic liver injuries are due to direct or indirect effects of the substance as well as the hepatotoxicity due to the

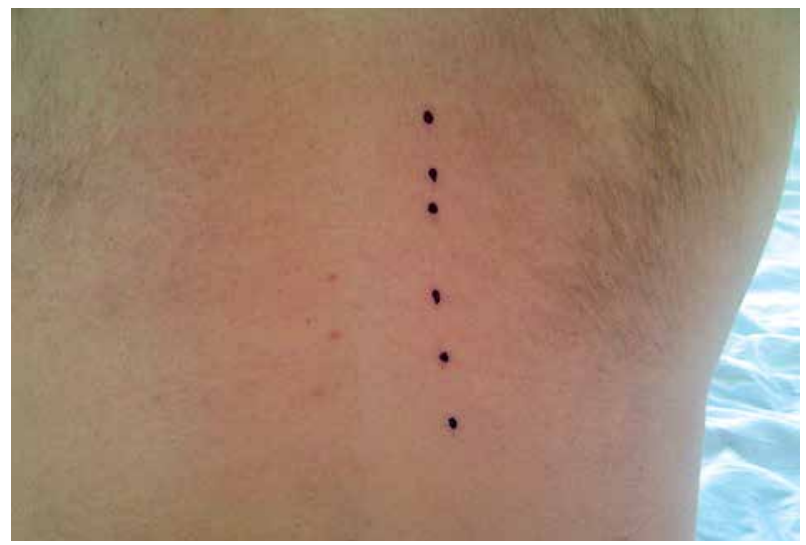

induction of immunological toxicities (drug-induced liver injury - DILI). A variety of peptide and organic compounds contained in herbal medicines are very frequent causes of DILI. The prevalence in Europe DILI is determined at $14-20$ per 100,000 inhabitants and is associated with non-specific effects of different chemical compounds. It seems that often damage to the liver occurs after activation of the various peptides and organic compounds in medicaments used in natural medicine [7]. There is a high probability that in the secretion of Phyllomedusa bicolor there are the toxins that can damage the liver.

\section{Disclosure}

Authors report no conflict of interest.

\section{References}

1. den Brave PS, Bruins E, Bronkhorst MW. Phyllomedusa bicolor skin secretion and the Kambô ritual. J Venom Anim Toxins Incl Trop Dis 2014; 20: 40.

2. Leban V, Kozelj G, Brvar M. The syndrome of inappropriate antidiuretic hormone secretion after giant leaf frog (Phyllomedusa bicolor) venom exposure. Toxicon 2016; 120: 107-109.

3. Pescatore R, Marrone GF, Sedberry S, et al. Synthesis and pharmacology of halogenated $\delta$-opioid-selective $[\mathrm{d}-\mathrm{Ala}(2)]$ deltorphin II peptide analogues. ACS Chem Neurosci 2015; 6: 905-910.

4. van Zoggel H, Carpentier G, Dos Santos C, et al. Antitumor and angiostatic activities of the antimicrobial peptide dermaseptin B2. PLoS One 2012; 9: e44351.

5. König E, Clark VC, Shaw C, et al. Molecular cloning of skin peptide precursor-encoding cDNAs from tibial gland secretion of the Giant Monkey Frog, Phyllomedusa bicolor (Hylidae, Anura). Peptides 2012; 2: 371-376.

6. Hemingway V, Brunner J, Speare R, et al. Viral and Bacterial Diseases in Amphibians. In: Amphibian Biology, Volume 8 Amphibian Decline: Disease, Parasites, Maladies, and Pollution. Heatwole H, Wilkinson JW (eds.). Surrey Beatty \& Sons, NSW 2009; pp. 29692986.

7. Spangenberg HC. Drug induced liver injury. Dtsch Med Wochenschr 2016; 23: 1688-1691. 